\title{
3-hydroxy-3-methylglutaryl-CoA synthase deficiency
}

INSERM

\section{Source}

INSERM. (1999). Orphanet: an online rare disease and orphan drug data base. 3-hydroxy3-methylg/utaryl-COA synthase deficiency. ORPHA:35701

3-hydroxy-3-methylg lutaryl-CoA synthase deficiency (HMG-CoA synthase deficiency) is a rare autosomal recessively inherited disorder of ketone body metabolism (see this term), reported in less than 20 patients to date, characterized clinically by episodes of decompensation (often associated with gastroenteritis or fasting) that present with vomiting, lethargy, hepatomegaly, non ketotic hypoglycemia and, in rare cases, coma. Patients are mostly asymptomatic between acute epidodes. HMG-CoA synthase deficiency requires an early diagnosis in order to avoid hypoglycemic crises that can lead to permanent brain damage or death. 